\title{
Understanding the Limitations to the Right to Strike in Essential and Public Services in the SADC Region
}

\section{R le Roux* and T Cohen**}

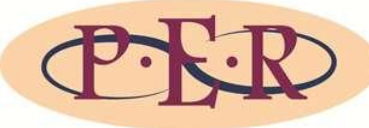

Author

Rochelle le Roux and Tamara Cohen

Affiliation

University of Cape Town and University of KwaZulu-Natal, South Africa

Email Rochelle.leroux@uct.ac.za cohen@ukzn.ac.za

Date published 18 May 2016

Editor Prof A du Plessis

How to cite this article

Le Roux $\mathrm{R}$ and Cohen $\mathrm{T}$

"Understanding the Limitations to the Right to Strike in Essential and

Public Services in the SADC

Region" PER / PELJ 2016(19) -

DOI

http://dx.doi.org/10.17159/1727-

3781/2016/v19i0a1161

\section{Copyright}

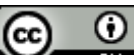

This work is licensed under a Creative Commons Attribution 4.0 International License.

DOI

http://dx.doi.org/10.17159/1727-

3781/2016/v19i0a1161

\begin{abstract}
The nature of the limitations to the right to strike in essential and public services in the nine sub-regional countries of Southern Africa - South Africa, Botswana, Lesotho, Namibia, Swaziland, Malawi, Mozambique, Zambia and Zimbabwe - is examined in this contribution. While all of these countries share common influences and face common challenges, there appears to be a vast disparity in the approaches taken to the right to strike in public and essential services in the region. A brief overview of the demographics and labour markets in the countries under discussion is sketched, the salient features of the ILO's approach to strike in essential and public services is highlighted, and a broad overview of the contrasting and disparate approaches to essential and public services in the region is provided. The focus is, however, on the legislative approach taken to essential service employees in South Africa. It is concluded that - with the exception of South Africa and Namibia - the limitations to the right to strike of public sector employees exceed those endorsed by international conventions, and the broad definition of essential services generally relied upon effectively results in an outright ban of public sector strikes in the sub-region.
\end{abstract}

\section{Keywords}

Right to strike; SADC region; essential services; public services. 


\section{Introduction}

From the early 1990s, major labour law reforms were implemented in Southern Africa. These reforms were driven by the adoption of new national constitutions (some entrenching the right to strike), a desire to democratise the workplace, and trade liberalisation. ${ }^{1}$ The countries analysed in this article have all formally endorsed the instruments of the International Labour Organisation (ILO) ${ }^{2}$ and have signed the Southern Africa Development Community (SADC) Social Charter (Charter of the Fundamental Social Rights in SADC (2003)). Despite this, and despite the ILO's active role in the region in promoting these standards, ${ }^{3}$ the right to strike remains poorly developed in the countries - outside South Africa. The right to strike in the essential services and public sector in the region is severely restricted. Given that the rate of informal employment in the region is high and that the public sector is the most important provider of formal employment in most of these countries, strikes are rare - with the exception of South Africa. ${ }^{4}$

This article examines the nature of the limitations to the right to strike in essential and public services in the nine sub-regional countries of Southern Africa: South Africa, Botswana, Lesotho, Namibia, Swaziland, Malawi, Mozambique, Zambia and Zimbabwe. While all of these countries share common influences and face common challenges posed by high

* $\quad$ Rochelle le Roux. BJuris (UPE), LLB (UPE), LLM (US), PGDip (Employment Law and Social Security) (UCT), LLM (Anglia Polytech(UK)), PhD (UCT). Professor, Faculty of Law and Director Institute of Development and Labour Law, University of Cape Town. E-mail: rochelle.leroux@uct.ac.za.

** Tamara Cohen. BA, LLB, LLM (University of Natal, Durban), PhD (University of KwaZulu- Natal). Associate Professor School of Law University of KwaZulu-Natal, Admitted attorney. E-mail: cohen@ukzn.ac.za.

1 Fenwick, Kalula and Landua "Labour Law" 175-177.

2 Freedom of Association and Protection of the Right to Organise Convention 87 (1948); Right to Organise and Collective Bargaining Convention 98 (1949).

3 ILO Report on the First Tripartite Seminar.

$4 \quad$ Fenwick, Kalula and Landua "Labour Law" 200. Most of the countries under discussion have relatively small (but fast growing) populations, and, consistent with their undeveloped status and poor infrastructure, education levels are low and life expectancy is poor. Mining (except in Lesotho and Swaziland) and tourism are important sources of gross domestic product, and, together with the public sector, are the most important providers of formal employment. Statistics are either not available or are poor and unreliable, but a 1999 report suggested that out of a population of 180-million in the SADC, only one in 10 has employment in the formal sector. See Tørres Labour Markets 13. A 1999 ILO report, reviewing amongst others 25 developing countries, indicates that public sector employment as a share of total employment is about $45 \%$ in Botswana and $15 \%$ in Malawi. See Hammouya Statistics on Public Sector Employment. Also see further country statistics at Trading Economics 2016 http://www.tradingeconomics.com; Nations Online 2015 http://www.nationsonline.com; and UNDP 2016 http://hdr.undp.org/en. 
unemployment rates, dire poverty, and bleak economic development, there appears to be a vast disparity in the approaches taken to the right to strike in public and essential services in the region. Of these countries, only South Africa (and to a lesser extent Namibia) follow a more nuanced approach to strikes in essential services. Yet strikes by essential service employees in South Africa such as nurses, doctors, municipal workers and employees essential to electricity generation and distribution are commonplace, often violent and disruptive, and are seemingly pursued without any consequences for the participating employees.

The structure of this article is as follows: in Section 2 we highlight the salient features of the ILO's approach to strikes in essential and public services. This is followed by a discussion in Section 3 of the more nuanced legislative approach to essential service employees in South Africa. In Section 4 we provide a broad overview of the contrasting and disparate approaches to essential and public services in the region. Our conclusion follows in Section 5.

\section{International law: The public service and essential services}

The right to strike is entrenched in the constitutions of South Africa, Zimbabwe, Malawi and Namibia, and in all the countries under consideration the right to strike is regulated by dedicated labour legislation. However, subsidiary legislation has often been relied upon to limit the application of these rights. ${ }^{5}$ Given the weak regional instruments and the prominent role of the ILO in the region, the validity of these limitations is best examined using the jurisprudence of the ILO's supervisory bodies as a matrix.

Despite the right to strike being only a derivative of ILO Conventions 87 and 98 , the jurisprudence of its supervisory bodies 6 is the most important source of international law when seeking guidance on limitations to the right to strike. Generally, this jurisprudence reflects deference to the right to strike - and the recognition of fairly narrow grounds for restricting the right. More specifically, this jurisprudence does not endorse a general ban on the right to strike of public sector employees (ie employees of the state). However, public services are rendered not only by public sector employees and, similarly, the ILO places no general restriction on the right to strike of

Fashoyin Public Policy 3.

The Committee of Experts on the Application of Conventions and Recommendations and the Governing Body on Freedom of Association. 
employees rendering a public service. In support of this, the Labour Relations (Public Service) Convention 151 (1978) provides that:

\begin{abstract}
...public employees shall have, as other workers, the civil and political rights which are essential for the normal exercise of freedom of association, subject only to the obligations arising from their status and the nature of their functions. ${ }^{7}$
\end{abstract}

Importantly (although this is less likely to be the case in the sub-region under discussion) essential services - which constitute a recognised area for the limitation of the right to strike - are not the exclusive domain of the public sector and can also be performed by those in private employment. ${ }^{8}$

Apart from the armed forces and the police, a limitation ${ }^{9}$ is acceptable only in the case of public servants exercising authority in the name of the state, or where they are performing essential services - provided that a speedy arbitration process is available. ${ }^{10}$ The identity of the public servants exercising "authority in the name of the state" will obviously depend on the nature of the function, but it is clear that a very limited band of public servants is intended. While it may include those employed by ministries or working in the administration of justice, it does not include those working in:

...oil, banking and metropolitan transport or those employed in the education sector and, more generally those who work in state companies and enterprises. ${ }^{11}$

Although a recognised area of limitation, the ILO has consistently maintained that essential services must be interpreted in very narrow terms, and that they relate only to those services, "the interruption of which would endanger the life, personal safety or health of the whole or part of the population". ${ }^{12}$ This is often referred to as "essential services in the strict sense"13 and suggests that, to constitute an essential service, there must be an acute danger or threat to the population.

7 Labour Relations (Public Service) Convention 151 (1978) concerns the freedom of association and procedures for determining conditions of employment in the public service.

8 Ruben Code of International Labour Law 208. A good example of this is the generation and supply of electricity - which, in many countries, has been privatised.

$9 \quad$ Gernigon, Odero and Guido 1998 Int'I Lab Rev 478.

10 ILO paras 118-119; Ruben Code of International Labour Law 209.

11 Gernigon, Odero and Guido 1998 Int'l Lab Rev 449.

12 Digest of decisions and principles of Freedom of Association Committee of the Governing Body of the ILO (1996) para 526 and 536.

13 ILO Freedom of Association paras 119-120. 
As an alternative, and realising that not everybody working in an essential service (in the strict sense) is necessarily rendering an essential service, the ILO supervisory bodies have endorsed negotiated minimum services instead of a total prohibition of strike action in that service. This implies that the strike action can continue provided that the minimum service is maintained. This, as will be shown below, is essentially the model endorsed by South African labour legislation. Furthermore, the ILO has also recognised a prohibition of strike action when a minimum service is agreed to in respect of: (1) a service that is not essential in the strict sense, but the cessation of which could nonetheless result in an "acute national crisis endangering the normal living conditions of the population"; ${ }^{14}$ and (2) public services of fundamental importance.$^{15}$ Examples of the latter include a ferry service to an island, basic transport services, postal services, refuse collection, or the continuation of examinations when teachers go on strike. ${ }^{16}$ These services are not essential services in the strict sense, but the inconvenience to or longer-term impact on the public when these services are not available are considered by the ILO as justification for a limitation of the right to strike. This is essentially the model endorsed by Italian legislation, that allows strikes in the services that impact on the personal rights protected by the Constitution of the Italian Republic, $1947^{17}$ - such as rights to life, health, health care, freedom and security, freedom of movement, social welfare, justice, education and freedom of communication - provided that a minimum service is maintained during strike action. ${ }^{18}$

In addition to minimum services in respect of these broadly public services, negotiated minimum services are also acceptable in order to comply with safety regulations and to minimise damage to and ensure the safe operation of machinery and plants.

\section{Essential services in South Africa}

Despite the fact that a more liberal approach to essential services was introduced in 1995, strikes in essential services in South Africa occur frequently. Table 1 (below) indicates the sectoral division of strikes in South Africa since 2007 - and highlights the frequent strike activity in the public sector in 2007 and 2010.

\footnotetext{
14 Digest of decisions and principles of Freedom of Association Committee of the Governing Body of the ILO (1996) para 558.

ILO Freedom of Association para 606.

ILO Freedom of Association paras 615-626.

It came into force on 1 January 1948.

Wedderburn Employment Rights 323.
} 
Table 1: Number of working days lost due to strikes (by nature of the organization) in South Africa

\begin{tabular}{|l|l|l|l|}
\hline Year & $\begin{array}{l}\text { Total } \\
\text { working days } \\
\text { lost }\end{array}$ & $\begin{array}{l}\text { Private } \\
\text { sector }\end{array}$ & Public sector \\
\hline 2013 & 1847006 & 1694085 & 53921 \\
\hline 2012 & 3309884 & 3224726 & 29490 \\
\hline 2011 & 2806656 & 2591437 & 215219 \\
\hline 2010 & 20674737 & 1230984 & 19443753 \\
\hline 2009 & 1526796 & 1267186 & 259610 \\
\hline 2008 & 497436 & 399222 & 98214 \\
\hline 2007 & 9528945 & 1383178 & 8145767 \\
\hline
\end{tabular}

Unfortunately, no data are available on the number of essential service workers participating in strike action, but focusing on 2007 and 2010, frequent strike activity is recorded in the sub-sectors where essential service workers would typically be found (electricity, gas, steam and hot water supply, health and social work, and local authority). ${ }^{19}$ This is supported by anecdotal reports and the explanatory memorandum to the Labour Relations Amendment Bill, 2013, which acknowledges the inadequacy of the dispute-resolution framework for essential services. ${ }^{20}$ Regardless of the sector, remuneration issues are consistently the principal cause of strike activity in South Africa.

Prior to the passing of the Labour Relations Act (LRA) in 1995, essential services in South Africa were regulated by different laws in different sectors. These were broadly defined and included services that were not remotely

19 Department of Labour 2007-2013 http://www.labour.gov.za/DOL/documents/annualreports/industrial-action-annual-report.

20 Explanatory Memorandum on Labour Relations Amendment Bill, 2013. 
"essential" in the sense contemplated by the ILO. ${ }^{21}$ Nonetheless, these prohibitions failed to prevent strikes in the services covered by them (primarily municipal services and nursing) - and were ineffective in preventing strikes in truly essential services. In 1995 the LRA - in recognition of the fundamental status given to the right to strike by the South African Constitution ${ }^{22}$ and borrowing from European countries - introduced a framework for the self-regulation of essential services, reflecting a desire to regulate by means of consensus and tripartism. ${ }^{23}$

The basic premise of the LRA (maintained after the recent amendments) is that strikes in essential services are prohibited and are subject to compulsory arbitration. ${ }^{24}$ However, essential services are understood in narrow terms and are determined independently. ${ }^{25}$ Nonetheless, parties are given an opportunity to reduce the ambit of such a designation (and thus strike prohibition) - by means of collective bargaining leading to a minimum service agreement. Such an agreement is now subject to ratification by the Essential Services Committee (ESC)-appointed panel. ${ }^{26}$ Once a minimum services agreement is ratified, only the workers rendering the minimum service cannot strike and the option of demanding arbitration in respect of the minimum service falls away.

The designations made by the ESC after 1995, despite the narrow definition of an essential service, remained fairly broad and seemed to identify sectors in which essential services are rendered - rather than the essential service itself. Perhaps this route was followed partly for the sake of expediency and partly in the mistaken belief that the ambit of these designations would be

21 Pillay 2001 ILJ 1.

22 Constitution of the Republic of South Africa, 1996.

23 Wedderburn Employment Rights 324.

24 As a consequence of this, strikes in essential services can be interdicted by the Labour Court. Disputes are subject to compulsory arbitration and workers participating in such unprotected strikes can be dismissed for misconduct.

25 The determination was previously made by the ESC, and since the recent amendments to the LRA by a panel appointed by the ESC. Hitherto, the requirements for membership of the ESC reflected only a limited recognition of tripartism, but the recent amendments provide for greater representation for the tripartite constituents, the appointment of a chairperson independent of these constituents, and for the appointment of investigative panels consisting of ESC members and representatives from the employer and union.

26 In an attempt to recognise the potentially devastating impact of a strike on private interests, the LRA further provides for the designation by the ESC of maintenance services (services the interruption of which has the effect of material physical destruction to any working area, plant or machinery) ie the prospect of economic loss because machines are not maintained is not sufficient (see $s 75$ of the Labour Relations Act 66 of 1995 (LRA SA)). Pillay 2001 ILJ 24. 
reduced by minimum service agreements. ${ }^{27}$ However, since the passing of the LRA, only two (now lapsed) minimum service agreements have been concluded and ratified by the ESC. This inability to conclude a minimum service agreement implies that it was not possible to moderate the limitation of the right to strike brought about by the designation of a service as essential. Legally, this left a union with a predicament: without a collective agreement, there is nothing for the ESC to ratify, and being in an essential service, the union cannot strike to force the employer to agree to a definition of a minimum service. However, in practice this has not dissuaded unions from striking. This practice is further tacitly encouraged by the failure of employers to discipline illegally striking workers and by the desire of unions not to divide the workforce between striking and non-striking workers - the former entitled to remuneration, and the latter not.

Since strikes in essential services are unprotected under the LRA, participating employees can be dismissed for misconduct, and both unions and employees can be liable for delictual and contractual damages. The Labour Court can also interdict strikes in essential services or any act in furtherance of such strikes, which, if ignored, can potentially lead to contempt procedures. However, in practice employers have not taken these actions out of fear of inciting the unions and further acts of violence and intimidation. ${ }^{28}$ Furthermore, no other penalties - administrative or criminal can be imposed against striking employees. Therefore, in practice essential services employees, apart from a loss of remuneration, have little to fear when striking.

Operational and administrative weaknesses aside, ${ }^{29}$ the voluntary nature of minimum service agreements and the consequent inability of the ESC to either urge the parties to agree on minimum services or, in the absence of agreement, to make binding proposals on minimum services appears to have posed major obstacles to their effectiveness. ${ }^{30}$ To address this, the recent amendments to the LRA provide that a panel appointed by the ESC may in future direct parties to negotiate a minimum services agreement within a period specified - failing which it may permit either party to refer the matter to conciliation at the Commission for Conciliation, Mediation and

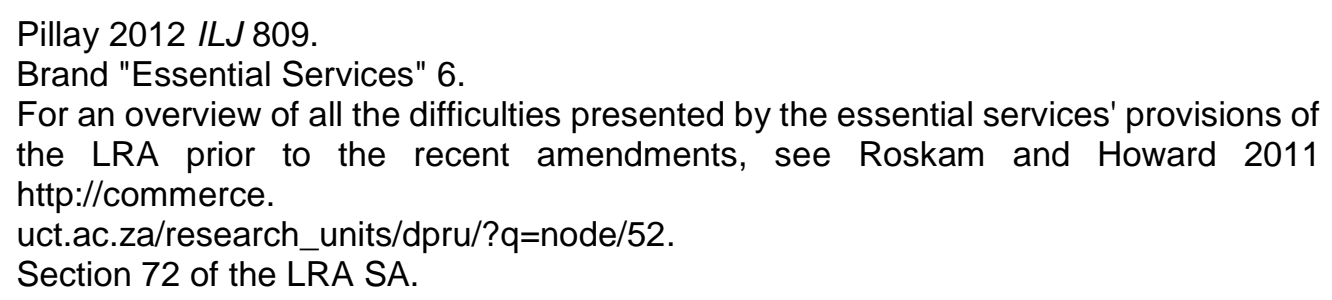


Arbitration $^{31}$ or a bargaining council having jurisdiction. If this fails, the Essential Services Committee may determine the minimum services that are required to be maintained in an essential service. The full impact of the amendment remains to be seen. It does not change the definition of essential services - and previous designations remain in force. The ESC is still required to ratify collective agreements providing for minimum services, but in future it will have powers to determine the minimum services required to be maintained in an essential service, where the parties fail to do so. However, the lack of any incentive, primarily by means of administrative penalties, and the absence of the powers of the ESC or any other body to halt or intervene in strikes in essential services may result in the perpetuation of the current disregard of essential services law.

\section{$4 \quad$ The right to strike in public and essential services in the SADC}

\subsection{Public sector employees and the right to strike}

In Lesotho and Zimbabwe, public and private sector employees are regulated in terms of separate legislation. In Lesotho, the Public Service Act (PSA) of $2005^{32}$ prohibits public officers from forming or joining trade unions and embarking on strike action. Public officers are nonetheless entitled to establish staff associations - however, collective bargaining has not taken off in this sector as the high threshold (of $50 \%+$ ) prescribed by the PSA has not been met. Instead, wages and conditions of service are determined unilaterally by the government. Disputes of interest in the public sector are subject to an advisory award by a conciliation board ${ }^{33}$ and only disputes in essential services in the public service are to be referred to arbitration. ${ }^{34}$ The Zimbabwean Constitution of 2013 (as amended) ${ }^{35}$ provides for the right of every person to freedom of association, assembly and expression, and to strike ${ }^{36}$ - and provides that, except for members of the security services, every person has the right to form and join a trade union and participate in its lawful activities. Despite this, public service employees in Zimbabwe are

\footnotetext{
31 An independent dispute resolution body established by the LRA SA.

32 The Public Service Act (PSA) of 1995 excluded public officers from the scope of the Labour Code and prohibited public officers from belonging to trade unions. Under pressure from workers' organisations and the ILO, the Public Service Act 1 of 2005 (PSA Lesotho) was subsequently enacted - which to date regulates public officers in Lesotho.

33 Section 17(4) of PSA Lesotho.

34 Section 18(3) of PSA Lesotho.

35 Constitution of Zimbabwe Amendment Act 20 of 2013.

36 The right to strike was included in the 2013 Constitution.
} 
regulated by the PSA, ${ }^{37}$ which applies to all employees rendering services to the government (except for the security services, judiciary, parliament and the intelligence services). Such employees do not have the right to engage in collective bargaining ${ }^{38}$ nor the right to strike - with the latter constituting misconduct in terms of the Public Service Regulations. ${ }^{39} \mathrm{~A}$ Public Service Commission is established that recognises employee associations, and provision is made for consultations in the place of collective bargaining. However, agreements reached between government and worker representatives are not binding on the government as an employer. ${ }^{40}$

In South Africa, Namibia, Botswana, Malawi, Swaziland, Mozambique and Zambia, public and private sector employees are subject to the same legislation. The South African LRA removed the traditional distinction made between public and private sector employees, and applies to all employees with the exception of the National Defence Force and State Security Agency. This unitary approach is also maintained in respect of the right to strike and limitations to the right - the only exception being the longer notice period that applies to public sector employees intending to strike.

In Mozambique, while the Labour Code 23 of 2007 extends the right to organise to public servants and state officials - excluding firefighters, prison guards and members of judicial authorities - public servants do not have the right to form or join trade unions nor the right to strike. ${ }^{41}$ The state promotes arbitration and governmental intervention as fundamental means to dispute resolution instead of collective bargaining. ${ }^{42}$

Labour relations in Zambia are governed by the Industrial and Labour Relations (Amendment) Act 30 of 1997, that confirms employees' rights to form or join a registered trade union and to participate in lawful union activities $^{43}$ - but does not apply to members of the defence or police force, prison service, security intelligence service, judges, registrars of the court,

\footnotetext{
37 Public Service Act 21 of 1995 (Ch 16:04) (PSA Zimbabwe).

38 Section 19(1) of PSA Zimbabwe.

39 Public Service Regulations SI 1 of 2000 1-72.

40 Madhuku 2012 UBLJ 3.

41 In May 2014, a Draft Public Administration Unionization Bill was passed, supporting the right of public officers (excluding employees and agents assigned to the Presidency, the entities responsible for collecting taxes, foreign trade, the forces of defence and security, correctional services, the national service, public welfare, and the magistracy) to join or form trade unions, but it still does not endorse the right of such employees to strike (Anon 2014 http://allafrica.com/stories/201405010474.html).

42 ITUC 2009 http://www.ituc-csi.org/IMG/pdf/Mozambique_report-final_2_.pdf.

43 Fashoyin Policy Reforms.
} 
magistrates, and local court justices. ${ }^{44}$ The Act further empowers the Minister - after consultation with the Tripartite Consultative Labour Council - to exclude any other person from the right to join a trade union. ${ }^{45}$ Governmental control is evidenced at all stages of the collective bargaining process, and collective agreements must be approved by the Minister before becoming binding on the signatory parties. ${ }^{46}$

In Swaziland the Industrial Relations Act of 2000, as amended, applies to all employees, public and private - except members of the defence force, the police force and correctional services. ${ }^{47}$ In addition, workers in exportprocessing zones and public officers are prohibited from forming and joining unions and may only join staff associations. The government is the country's biggest employer and, through the Ministry of Public Administration, Employment and Social Security, sets wages and benefits on an annual basis. This involves consultation but no negotiations with the representative unions - and this clearly impedes public sector workers' exercise of their right to freedom of association.

In Botswana the Trade Union and Employers Organisation Act, as amended, extended collective bargaining rights to public servants for the first time. Except for the police, defence force and prison services and certain categories of essential services, there is no general ban on striking and the freedom to strike extends to both private and public sector employees. The Trade Dispute $A c t^{48}$ of 2004 , which applies to all employees excluding members of the disciplined forces ${ }^{49}$ and prison services, ${ }^{50}$ establishes the procedures for settlements of trade disputes, sets the standards for collective labour agreements, and defines and governs unlawful industrial action. ${ }^{51}$

44 Sections 2(1)(a)-(d) of the Industrial and Labour Relations (Amendment) Act 30 of 1997.

45 Section 2(2) of the Industrial and Labour Relations (Amendment) Act 30 of 1997.

46 Section 71(3) of the Industrial and Labour Relations (Amendment) Act 30 of 1997.

47 Section 3 of the Industrial Relations Act 1 of 2000.

48 Section 15 of the Trade Dispute Act 15 of 2004.

49 This includes the Botswana Defence Force, Botswana Police Service, and Local Police Service. S 2 of the Trade Dispute Act 15 of 2004.

50 In terms of s 2(11)(iv) the Trade Dispute Act 15 of 2004, s 2(1)(iv) of the Trade Union and Employer's Organisation (Amendment) Act 16 of 2003, and s 35 of the Prisons Act 28 of 1979, employees of the prison services are prohibited from joining a trade union. In terms of the Prisons Act, any prisons officer who becomes a member of a trade union or anybody affiliated to a trade union shall be liable to be dismissed from the service.

51 Friedrich Ebert Foundation 2008 http://www.fes-botswana.org/media/pdf/TradeUnion Report2008.pdf. 
The Namibian Constitution provides for the right to strike as a fundamental right for the purpose of collective bargaining, and the Labour Act of 2007 applies to all employees - public and private sector alike - except military, police and prison staff. ${ }^{52}$ In Malawi, the Labour Relations Act of 1996 and Employment Act of 2000 apply to all employees ${ }^{53}$ - with the exception of the armed forces, the prison service and the police - except those employed in a civilian capacity. ${ }^{54}$ In terms of this legislation, collective bargaining rights, including the right to strike, are extended to all parties that attain a $20 \%$ membership threshold. ${ }^{55}$ Nonetheless, public sector reforms such as government fiscal discipline, as part of World Bank and IMF reforms, have placed severe constraints on the collective bargaining process, particularly in relation to public sector bargaining that is curtailed by the national budget and IMF conditionality.

\subsection{Essential services employees and the resolution of disputes}

Strikes are not permissible in essential services in all the countries under consideration. In Lesotho, essential services are defined by the Labour Code of 2007 as:

...undertakings that provide a service whose interruption would endanger the life, personal safety or health of all or any part of the population of Lesotho. ${ }^{56}$

Despite this definition (that seemingly complies with the ILO's "strict" definition of essential services) the Labour Code (Essential Services) Regulations, 1997 designates a wide range of services as essential including health and hospital services, electricity and water-supply services, sanitary services, fire prevention and extinguishing services, transport services, telecommunication services, air-traffic control, and transport services necessary to the afore-mentioned services. This list fails to distinguish between essential and non-essential employees within such services, therefore casting the net of essential services very wide. Disputes in essential services must be resolved by compulsory arbitration.

52 Sections 2(2)(a)-(d) of the Labour Act 11 of 2007 excludes members of the Namibian Defence Force, Namibian Police Force, and a municipal police service referred to in the Police Act 19 of 1990, the Namibian Central Intelligence Service, and the Prison Service - unless the applicable legislation provides otherwise.

53 Dzimbiri 2013 http://www.ndr.mw:8080/xmlui/bitstream/handle/123456789/941/industrial\%20 relations\%20in\%20malawi.pdf.

54 Section 3 of the Labour Relations Act 16 of 1996 (LRA Malawi).

55 Section 25(1) of the LRA Malawi.

56 Labour Code 2007 s 232(1). 
Similarly, in Zimbabwe an essential service is defined as being:

..any service the interruption of which endangers immediately the life, personal safety or health of the whole or part of the public... ${ }^{57}$

and must be declared an essential service by the Minister in the government gazette. ${ }^{58}$ The Labour (Declaration of Essential Services) Notice, 2003 declared an extensive list of services as essential, ${ }^{59}$ and fails to distinguish between the services actually performed by employees within the "essential" services identified. Disputes in these services that have not been settled within 30 days or such other period as agreed to by the parties will be referred to compulsory arbitration. ${ }^{60}$ Employees in the health sector are regulated by the Health Services Act, ${ }^{61}$ which recognises their rights to form associations but does not recognise the right to strike. All employees in the health sector are classified as essential services, with no legal right to conclude binding collective agreements and no right to strike. ${ }^{62}$

In Zambia essential services are widely specified as meaning: any service relating to the generation, supply or distribution of electricity; any hospital or medical service; any service relating to the supply and distribution of water; any sewerage service; any fire brigade; or any service for the maintenance of safe and sound conditions in a mine or underground working and drainage, shafts and shaft installations or machinery and plants; and such other service which the Minister may, in consultation with the Tripartite Consultative Labour Council, prescribe by statutory instrument as being an essential service. ${ }^{63}$ Disputes involving a party engaged in an essential service must be referred directly to the Industrial Relations Court rather than referred for conciliation, ${ }^{64}$ and the court has one year from the day on which the dispute is referred to dispose of the matter. ${ }^{65}$

57 Labour Act [Chapter 28:01] s 102.

58 Labour Act [Chapter 28:01] s 102.

59 The list includes, amongst others: fire services; supply and distribution of water, veterinary services, health services, transport and communication services, electrical services provided by a person licensed under the Electricity Act, and services provided by any public broadcaster during a state of disaster or an emergency likely to be declared a state of disaster.

60 Labour Act [Chapter 28:01] s 93.

61 Health Services Act 28 of 2004 (Ch 15:16).

62 ITUC 2013 http://survey.ituc-csi.org/Zimbabwe.html?lang=en\#tabs-2.

63 Section 108 of the Industrial and Labour Relations Act (Vol 15, Cap 269) (ILRA Zambia).

64 Section 85(3) of the ILRA Zambia. In terms of $s 76$, the court has one year from the day on which the dispute is referred, to dispose of the matter.

65 Section 85(3) of the ILRA Zambia. 
In Swaziland, the Industrial Relations Act defines essential services as being services:

...by whomsoever such services are rendered, and whether rendered to the Government or to any other person... ${ }^{66}$

in respect of water services; electricity services; fire services; health services; sanitary services; telephone, telegraph and broadcasting services; and any service in the civil capacity in respect of the government of Swaziland. ${ }^{67}$ The Minister is empowered to modify this list of essential services.

In Botswana, essential services are defined in the Trade Dispute Act as "any of the services contained in the schedule", 68 which may be amended by the Minister by publishing an order in the Government Gazette. Prior to 2011 the schedule listed essential services as including air-traffic control services, the vaccine laboratory, fire services, the Bank of Botswana, health services, railways operations and maintenance services, sewerage services, transport and telecommunication services necessary to the operation of the foregoing services, and water services. Essential services are further defined in the Public Services Act as:

...those services the interruption of which would endanger the life, personal safety or health of a whole or part of the population... ${ }^{69}$

and includes the services listed under the schedule to the Trade Dispute Act. Clearly, some of the designated services - notably the Bank of Botswana and the railway services - exceed the "strict" definition of essential services advocated by the ILO.

In 2011 public officers in Botswana embarked on unprecedented industrial action for the first time in the history of the country ${ }^{70}$ - lasting almost two months. As a consequence of these public sector strikes, almost 3000 essential services employees were collectively dismissed without a hearing for taking part in an illegal strike and failing to comply with a strike interdict and various ultimatums to return to work. The fairness of their dismissals

66 Section 73 of the Industrial Relations Act, 1996.

67 Similarly, in Mozambique the list of essential services is very broad, and includes postal, meteorological and other services - as well as services rendered in exportprocessing zones which are not essential in the strict sense of the term. ITUC 2009 http://www.ituc-csi.org//MG/pdf/Mozambique_report-final_2_.pdf.

68 Trade Dispute Act, $2003 \mathrm{~s} 2$.

69 Public Service Act, $2008 \mathrm{~s} 49$.

70 Baakile and Tshukudu 2012 JPAG 127. 
was eventually confirmed by the Court of Appeal..$^{71}$ In reaching its decision the Court rejected the argument that only those strikers performing "essential" jobs within the essential services ought to be dismissed - noting that in Botswana:

\section{...all employees in an essential service play an important role individually towards ensuring the effectiveness of the team delivering the essential service in question ${ }^{72}$}

and no basis exists for distinguishing them. The Court of Appeal was satisfied that, in the circumstances, all essential services' strikers were fairly dismissed.

In Mozambique arbitration is compulsory in essential services. The list is very broad and includes postal, meteorological and other services as well as services rendered in export-processing zones which are not essential in the strict sense of the term. ${ }^{73}$ In Malawi an essential service is defined as:

\footnotetext{
...services, by whomsoever rendered, and whether rendered to the Government or to any other person, the interruption of which would endanger the life, health or personal safety of the whole or part of the population. ${ }^{74}$
}

The broad scope of the definition and the failure to specify the criteria for the determination of essential services casts the net of essential services very wide, and effectively encompasses much of the public service. The LRA (Malawi) makes provision for the Minister to apply at any time to the Industrial Relations Court for a determination as to whether a threatened or actual strike or lockout involves an essential service. ${ }^{75}$ Employees engaged in an essential service shall not strike, and unresolved disputes may be referred by either party to the dispute or the Principal Secretary responsible for labour - to the Industrial Relations Court for the determination of the dispute. ${ }^{76}$

In South Africa the LRA provides for the limitation of the right to strike in respect of essential services, but once again makes no specific distinction between private and public sector employees. Nonetheless, the practical impact of the limitation remains most visible in the public sector. Except for

71 Attorney General v Botswana Landboards and Local Authorities Workers' Union 2013 34 ILJ 1875 (BotCA).

72 Attorney General v Botswana Landboards and Local Authorities Workers' Union 2013 34 ILJ 1875 (BotCA) 1911.

73 It is reported that in the Mozal export-processing zone, unionists face discrimination and unfair dismissals for going on strike or for trying to organise.

74 Section 2 of LRA Malawi.

75 Section 47(2) of LRA Malawi.

76 Section 45(1) of LRA Malawi. 
the parliamentary service and the South African Police Service, ${ }^{77}$ the Act does not follow a "list" approach; instead, the designation of a service as essential is determined exclusively by an ESC, as discussed above. Consistent with the ILO's approach, the LRA defines an essential service in very narrow terms, as a service the interruption of which endangers the life, personal safety or health of the whole or any part of the population (and makes no purposeful distinction between services rendered by private and public institutions). Interest disputes in essential services are subject to compulsory arbitration.

The only country in the SADC that follows the South African model of determination is Namibia. The Namibian Labour Act of 2007 prohibits strikes in essential services, but does not list essential services. Instead the designation of an essential service is recommended by an ESC, and is finally determined by the Minister of Labour. Designations are made with reference to the same narrow definition as is applied in South Africa. ${ }^{78}$ Disputes in essential services are to be resolved by a mandatory arbitration process.

\subsection{Consequences of participation in an unlawful strike}

In many of the SADC countries, industrial action by essential services and public service employees is criminalised - with serious consequences for striking employees. Zambian legislation prescribes civil or penal sanctions for workers and unions involved in non-authorised strike actions, including fines and imprisonment and sanctions for damages caused by strike actions. In Swaziland, an employer or employee engaged in strike action or a lockout in an essential service is liable to a fine or imprisonment. Similarly, an organisation or federation (or union official) that calls for or causes illegal strike action or a strike in an essential service shall be guilty of an offence and liable for a fine or imprisonment. In addition to these penalties, the court may order the cancellation or suspension of a union's registration, and an employee taking part in illegal strike action may have his contract of employment summarily terminated. A trade union faces civil liability and

77 Section 71 of LRA SA. The SAPS consists of members and support personnel appointed under different legislation. In SA Police Service $v$ Police and Prisons Civil Rights Union 201132 ILJ 1603 (CC), the Constitutional Court, relying purely on legislative interpretation, concluded that support personnel were not members of SAPS and are therefore free to strike.

78 The Act defines essential services as: "a service the interruption of which would endanger the life, personal safety or health of the whole or any part of the population of Namibia and which has been designated as such in terms of section 77 of the Labour Act No 11 of 2007". 
criminal liability for any damage caused or for other "unlawful behaviour" during strikes. The State of Emergency, in force in Swaziland since 1973, has resulted in the suspension of constitutional freedoms, and trade unions face a difficult legal environment. ${ }^{79}$ The Suppression of Terrorism Act, ${ }^{80}$ renewed in 2010 , has been utilised to repress trade unions and to prohibit them from engaging in activities that are deemed "political" in nature. ${ }^{81}$ In this regard the ILO's supervisory body has regularly criticised the governmental interference in union affairs - particularly those of public service unions.

In Botswana the Public Service Act provides that public officers that wilfully breach their employment contract, with the effect that the public is deprived of an essential service, commit a criminal offence in the absence of a credible defence. ${ }^{82}$ Section 43 of the Trade Dispute Act similarly stipulates that a person who wilfully breaches his contract so as to deprive the public or part thereof of an essential service, or to endanger human life or public health, or cause serious bodily injury to any person, or to expose valuable property whether movable or immovable to the risk of destruction, deterioration, loss or serious damage, commits an offence. ${ }^{83}$ This liability extends to any:

...person who causes, procures, counsels, or influences any employee to breach his contract of employment...84

on this basis and is intended to implicate trade union officials. In Mozambique, the Labour Act provides for fines for strikes and pickets that disrupt the normal operation of services. Any violation of the right to work of non-strikers, and in respect of minimum services, is a disciplinary offence and renders striking workers liable to civil and penal sanctions. ${ }^{85}$ In Zimbabwe, the rights of trade unions have been severely compromised by security legislation ${ }^{86}$ under which acts and opinions considered detrimental

79 ITUC 2012 http://www.refworld.org/docid/4fd8892413.html cites instances of repeated arbitrary arrests, intimidation and beatings of trade unionists and the violent repression of protests by the police and army.

80 Suppression of Terrorism Act 3 of 2008.

81 US Department of State 2014 http://www.refworld.org/docid/53284a685.html.

82 Sections 49(4) and (5) of PSA Botswana.

83 Section 45 of the Trade Dispute Act 15 of 2004 purports to legalise an essential service strike in the private sector, provided that conditions laid down in the provision are met. Essential service strikes in the public sector are not included in that provision, and constitute a criminal offence.

84 Section 45 of the Trade Dispute Act.

85 ITUC 2012 http://www.refworld.org/docid/4fd88934c.html.

86 Public Order and Security Act of 2002 (Ch 11:17) and the Criminal Law (Codification and Reform) Act of 2006 (Ch 9:23). 
to the public order or interest are punishable by up to five years of imprisonment. Police and security forces have relied extensively upon these laws to repress basic civil liberties and trade union rights. ${ }^{87}$ An ILO Commission of Inquiry into breaches of Conventions 87 and 89 concluded that there has been systematic and even systemic violation of the Conventions in Zimbabwe - evidenced in the arrests, detentions, violence and torture of trade union leaders, the targeting of trade union officials and members, and the routine use of the police and army against strikes. ${ }^{88}$

Although striking in an essential service in South Africa can potentially lead to a misconduct dismissal or possibly civil liability on the part of the organising union or the strikers, there are no criminal implications for striking in an essential service. A similar approach is adopted in Namibia and Malawi.

\section{Conclusion}

This analysis has shown that, with the exception of South Africa and Namibia, limitations to the right to strike of public sector employees in the SADC exceed those endorsed by international conventions. In particular, limitations to freedom of association in the public sector are commonplace, and limitations to the right to strike vary from an outright ban to a ban by subterfuge. In other words, even where strikes are generally permitted in the public sector and prohibited only in defined essential services, a broad definition of essential services or a determination of essential services swayed by governmental influence and interests effectively results in an outright ban of public sector strikes in the sub-region.

In South Africa the determination of an essential service is performed by an independent body with the opportunity for stakeholders to reduce the impact of the limitation to strike in these services - by carving out minimum services by collective agreement. This has not been effective thus far, and while recent amendments give the ESC a greater influence in the determination of minimum services, their impact remains to be seen. Regardless of these amendments, the process of determining essential (and minimum) services in South Africa remains removed from executive decision making - in contrast to the situation in most of the other countries reviewed, where

87 Sections 17 and 19 of Public Order and Security Act of 2002; s 37 of the Criminal Law (Codification and Reform) Act of 2006.

88 ILO Commission of Inquiry 2010 http://www.ilo.org/dyn/normlex/ en/f?p=1000:50012:0::NO:50012:P50012_COMPLAINT_PROCEDURE_ID,P50012_ LANG_CODE:2508373,en:NO. 
essential services are either pre-determined by legislation or finally determined by executive power. Where these determinations have been challenged in the regional courts, the courts have been inclined to favour a limitation of the right to strike, taking cognisance of the broader and longerterm impact of strikes. On the face of it, this seems to be inconsistent with international law.

While it is apparent that many of the services (in the region) that are categorised as essential services in the strict sense do not belong to that category, in reality they are generally clearly public services of fundamental importance. It can therefore be asked whether the approach in the region to limit strikes in these services is not a justifiable implementation of the proportionality principle that is embedded in ILO jurisprudence. ${ }^{89}$ It is likely that the development of the right to strike in the region and the interests of the population would be better served by promoting the conclusion of minimum service agreements in these services - instead of persisting with the focus on the narrow definition of essential services. As is demonstrated by the "more sophisticated" model in South Africa, the narrow focus on essential services and the identification of minimum services by selfregulation has led to equally undesirable outcomes.

\section{Bibliography}

\section{Literature}

Baakile and Tshukudu 2012 JPAG

Baakile $M$ and Tshukudu T "Deep Rooted Conflicts and Industrial Relations Interface in Botswana" 2012 JPAG 118-133

Brand "Essential Services"

Brand $\mathrm{J}$ "Essential Services and the Implications of Minimum Service Agreements in the Public Sector" in $3^{\text {rd }}$ Biennial Labour Relations Conference (24 October 2013)

Ewing "Laws against Strikes Revisited"

Ewing K "Laws against Strikes Revisited" in Barnard C, Deakin S and Morris G (eds) The Future of Labour Law (Bloomsbury London 2004) 41-61

Fashoyin Public Policy

Fashoyin T Public Policy and Trade Disputes in the Public Service in Southern Africa: Need for Policy Coherence (ILO Geneva 2007)

89 Ewing "Laws against Strikes Revisited" 53-54. 
Fashoyin Policy Reforms

Fashoyin T Policy Reforms and Employment Relations in Zambia (ILO Geneva 2008)

Fenwick, Kalula and Landua "Labour Law"

Fenwick C, Kalula E and Landua I "Labour Law: A Southern African Perspective" in Teklè T (ed) Labour Law and Worker Protection in Developing Countries (Hart Oxford 2010) 175-224

Gernigon, Odero and Guido 1998 Int'l Lab Rev

Gernigon B, Odero A and Guido H "ILO Principles Concerning the Right to Strike" 1998 Int'l Lab Rev 441-481

Hammouya Statistics on Public Sector Employment

Hammouya M Statistics on Public Sector Employment: Methodology, Structure and Trends (ILO Bureau of Statistics Geneva 1999)

ILO Digest

Digest of decisions and principles of Freedom of Association Committee of the Governing Body of the ILO (1996) para 526 and 536

ILO Freedom of Association

International Labour Organisation Freedom of Association: Digest of Decisions and Principles of the Freedom of Association Committee of the Governing Body of the ILO (ILO Geneva 2006)

ILO Report on the First Tripartite Seminar International Labour Organisation Report on the First Tripartite Seminar on National and International Labour Standards in Southern Africa (Englishspeaking Countries): Swakopmund, Namibia, 16-20 May 1994 (ILO Geneva 1994)

Madhuku 2012 UBLJ

Madhuku $L$ "The Alternative Labour Dispute Resolution System in Zimbabwe: Some Comparative Perspectives" 2012 UBLJ 3-44

Pillay 2001 ILJ

Pillay D "Essential Services Under the New LRA" 2001 ILJ 1-36

Pillay 2012 ILJ

Pillay D "Essential Services: Developing Tools for Minimum Service Agreements" 2012 ILJ 801-820 
Ruben Code of International Labour Law

Ruben N (ed) Code of International Labour Law (Volume 1 - Essentials of International Law) (Cambridge University Press Cambridge 2005)

Tørres Labour Markets

Tørres L Labour Markets in Southern Africa (Fafo Institute for Applied Social Science Oslo 1998)

Wedderburn Employment Rights

Wedderburn K Employment Rights in Britain and Europe: Selected Papers in Labour Law (Lawrence and Wishart London 1991)

\section{Case law}

Attorney General v Botswana Landboards and Local Authorities Workers' Union 201334 ILJ 1875 (BotCA)

SA Police Service v Police and Prisons Civil Rights Union 201132 ILJ 1603 (CC)

\section{Legislation}

\section{Botswana}

Prisons Act 28 of 1979

Public Service Act (Act No. 30 of 2008) (Cap. 26:01)

Trade Dispute Act 15 of 2004

Trade Union and Employers Organisation Act (Ch 48:01)

Trade Union and Employers Organisation (Amendment) Act of 16 of 2003

Italy

Constitution of the Italian Republic, 1947

\section{Lesotho}

Labour Code (Essential Services) Regulations, 1997

Public Service Act (PSA) of 1995

Public Service Act (PSA) 1 of 2005

\section{Malawi}

Employment Act 6 of 2000

Labour Relations Act 16 of 1996

\section{Mozambique}

Draft Public Administration Unionization Bill, 2014

Labour Code 23 of 2007 


\section{Namibia}

Constitution of the Republic of Namibia, 1990

Labour Act 11 of 2007

Police Act 19 of 1990

\section{South Africa}

Constitution of the Republic of South Africa, 1996

Labour Relations Act 66 of 1995

Labour Relations Amendment Bill, 2013

\section{Swaziland}

Industrial Relations Act, 1996.

Industrial Relations Act 1 of 2000

Suppression of Terrorism Act 3 of 2008

\section{Zambia}

Industrial and Labour Relations Act (Vol 15, Cap 269)

Industrial and Labour Relations (Amendment) Act 30 of 1997

\section{Zimbabwe}

Constitution of Zimbabwe Amendment Act 20 of 2013

Criminal Law (Codification and Reform) Act of 2006 (Ch 9:23)

Health Services Act 28 of 2004 (Ch 15:16)

Labour Act 2007 [Chapter 28:01) (as amended 01/02/2006)

Labour (Declaration of Essential Services) Notice, 2003

Public Order and Security Act of 2002 (Ch 11:17)

Public Service Act 21 of 1995 (Ch 16:04)

Public Service Regulations SI 1 of 2000

\section{International instruments}

Freedom of Association and Protection of the Right to Organise Convention $87(1948)$

Labour Relations (Public Service) Convention 151 (1978)

Right to Organise and Collective Bargaining Convention 98 (1949)

Charter of the Fundamental Social Rights in SADC (2003) 


\section{Internet sources}

Anon $2014 \mathrm{http}: / /$ allafrica.com/stories/201405010474.html

Anon 2014 Mozambique: Assembly Grants Trade Union Rights to State Workers http://allafrica.com/stories/201405010474.html accessed 8 October 2014

Department of Labour 2007-2013 http://www.labour.gov.za/DOL/ documents/annual-reports/industrial-action-annual-report

Department of Labour 2007-2013 Industrial Action Report http://www.labour.gov.za/DOL/documents/annual-reports/industrial-actionannual-report accessed 8 October 2014

Dzimbiri 2013 http://www.ndr.mw:8080/xmlui/bitstream/handle/123456789/ 941/industrial\%20relations\%20in\%20malawi.pdf

Dzimbiri L 2013 Industrial Relations in Malawi http://www.ndr. mw:8080/xmlui/bitstream/handle/123456789/941/industrial\%20relations\% 20in\%20malawi.pdf accessed 8 October 2014

Friedrich Ebert Foundation 2008 http://www.fes-botswana.org/media/pdf/ TradeUnionReport2008.pdf

Friedrich Ebert Foundation 2008 Trade Unions in Botswana Country Report 2008 http://www.fes-botswana.org/media/pdf/TradeUnionReport2008.pdf accessed 8 October 2014

ILO Commission of Inquiry 2010 http://www.ilo.org/dyn/normlex/ en/f?p=1000:50012:0::NO:50012:P50012_COMPLAINT_PROCEDURE_I D,P50012_LANG_CODE:2508373,en:NO International Labour Organisation Commission of Inquiry 2010 Report of the Commission of Inquiry Appointed Under Article 26 of the Constitution of the International Labour Organization to Examine the Observance by the Government of Zimbabwe of the Freedom of Association and Protection of the Right to Organise Convention, 1948 (No 87), and the Right to Organise and Collective Bargaining Convention, 1949 (No 98) http://www.ilo.org/dyn/normlex/en/f?p=1000:50012:0::NO:50012:P50012 COMPLAINT_PROCEDURE_ID,P50012_LANG_CODE:2508373,en:NO accessed 8 October 2014

ITUC 2009 http://www.ituc-csi.org/IMG/pdf/Mozambique_reportfinal_2_.pdf

International Trade Union Confederation 2009 Internationally Recognised Core Labour Standards in Mozambique Report for the WTO General Council Review of the Trade Policies of Mozambique (Geneva, 22 and 24 
April 2009) http://www.ituc-csi.org//MG/pdf/Mozambique_report-final_2 _.pdf accessed 8 October 2014

ITUC 2012 http://www.refworld.org/docid/4fd88934c.html International Trade Union Confederation 20122012 Annual Survey of Violations of Trade Union Rights - Mozambique http://www.refworld.org/docid/4fd88934c.html accessed 17 September 2014

ITUC 2012 http://www.refworld.org/docid/4fd8892413.html International Trade Union Confederation 20122012 Annual Survey of Violations of Trade Union Rights - Swaziland http://www.refworld.org/docid/4fd8892413.html accessed 8 October 2014

ITUC 2013 http://survey.ituc-csi.org/Zimbabwe.html?lang=en\#tabs-2 International Trade Union Confederation 2013 Survey of Violations of Trade Union Rights - Zimbabwe http://survey.ituc-csi.org/Zimbabwe.html?lang=en \#tabs-2 accessed 8 October 2014

Nations Online 2015 http://www.nationsonline.com Nations Online 2015 Home Page http://www.nationsonline.com accessed 21 March 2016

Roskam and Howard 2011 http://commerce.uct.ac.za/research_units/ dpru/?q=node/52

Roskam A and Howard N 2011 A Model for the Reregulation of Essential Services (Report Prepared for the Employment Promotion Programme) http://commerce.uct.ac.za/research_units/dpru/?q=node/52 accessed 8 October 2014

Trading Economics 2016 http://www.tradingeconomics.com

Trading Economics 2016 Home Page http://www.tradingeconomics.com accessed 21 March 2016

UNDP 2016 http://hdr.undp.org/en

United Nations Development Programme 2016 Human Development Reports http://hdr.undp.org/en accessed 21 March 2016

US Department of State 2014 http://www.refworld.org/docid/ 53284a685.html

United States Department of State 20142013 Country Reports on Human Rights Practices - Swaziland http://www.refworld.org/docid/53284a685.html accessed 8 October 2014 


\section{List of Abbreviations}

ESC

ILJ

ILO

Int'I Lab Rev

ITUC

JPAG

LRA

PSA

SADC

SAPS

UBLJ

UNDP
Essential Services Committee

Industrial Law Journal

International Labour Organisation

International Labour Review

International Trade Union Confederation

Journal of Public Administration and Governance Labour Relations Act

Public Service Act

Southern Africa Development Community

South African Police Service

University of Botswana Law Journal

United Nations Development Programme 